\title{
Pengaruh Struktur Kepemilikan dan Dewan Komisaris Terhadap Tingkat Pengungkapan Risiko pada Bank Syariah
}

\author{
Ika Swasti Putri ${ }^{1}$, Yuniatin TDKW ${ }^{2}$ \\ STIE Adi Unggul Bhirawa Surakarta \\ Jl. Mr. Sartono No. 97 Ngemplak Jebres Surakarta \\ ika@stie-aub.ac.id
}

\begin{abstract}
This research purpose to get empirical proof about the influences of profitability degree (ROA), public share ownership, commissioner with the Islamic economic background, and commissioner with background from Islamic banking supervisory institution to Risk Disclosure Index. This research is quantitative research and using secondary data form of an annual report on Islamic Banks in Indonesia for the period 2012-2018, with the samples used amounted to 11 Islamis Banks. This research uses purposive sampling to carry out sample selection. Statistic method that used for examining the hypothesis is multiple regression analysis. The result of this research showed that public share ownership and commissioner with the Islamic economic background are positive related significant with the level of risk disclosure. While the variables of profitability and commissioner with background from Islamic banking supervisory institution are not significant on the level of risk disclosure. Based on the research also found that the four variables simultaneously has influence to Risk Disclosure for $23,7 \%$.
\end{abstract}

\begin{abstract}
Abstrak- Penelitian ini dilakukan untuk menguji pengaruh profitabilitas (ROA), jumlah kepemilikan saham publik, proporsi dewan komisaris dengan latar belakang ekonomi Islam dan proporsi dewan komisaris dengan latar belakang pensiunan dari otoritas pengawas perbankan syariah terhadap Tingkat Pengungkapan Risiko Bank Syariah (Risk Disclosure Index). Penelitian ini merupaka n penelitian kuantitatif dengan menggunakan data sekunder berupa laporan tahunan Bank Umum Syariah di indonesia periode 20122018, dengan sampel yang digunakan berjumlah 11 Bank Umum Syariah. Penelitian ini menggunakan purposive sampling sebagai metode pemilihan sampel. Metode statistik yang digunakan untuk pengujian hipotesis adalah analisis regresi berganda. Hasil analisis menunjukkan bahwa kepemilikan publik dan dewan komisaris dengan latar belakang ekonomi Islam berpengaruh positif terhadap pengungkapan risiko pada bank syariah di Indonesia sedangkan dewan komisaris dengan latar belakang pensiunan dari otoritas pengawas perbankan syariah dan profitabilitas tidak memiliki pengaruh terhadap tingkat pengungkapan risiko bank syariah. Berdasarkan hasil penelitian juga menemukan bahwa secara simultan kedelapan variabel mampu mempengaruhi tingkat pengungkapan risiko sebesar $23,7 \%$.
\end{abstract}

Kata Kunci- Risiko profitabilitas, kepemilikan saham publik, dewan komisaris.

\section{PENDAHULUAN}

Bank Syariah yaitu bank yang melakukan operasi dengan menggunakan prinsip dasar syariah Islam dan tidak menggunakan bunga pada kegiatan operasinya. Bank Syariah juga salah satu sektor keuangan yang menjadi pilar ekonomi Indonesia. Bank syariah yang dalam pelaksanaan fungsi pelayanan jasa keuangan dan bank syariah di Indonesia mengalami kemajuan yang pesat dan syarat akan persaingan sehingga perbankan yang sehat akan memenangkan persaingan. Dengan pesatnya perkembangan perbankan syariah di Indonesia dan untuk memenangkan persaingan dalam hal ini lancarnya arus investasi, para investor dituntut untuk berpikir dan bertindak cerdas, teliti dan tepat dalam pengambilan keputusan terkait investasi. Oleh karena itu, investor membutuhkan informasi mengenai kondisi kesehatan bank sebelum melakukan investasi. Pengungkapan risiko perusahaan / bank dapat dijadikan alat informasi bagi investor untuk pengambilan keputusan dalam melakukan investasi. Menurut Adiyanto (2015) pengungkapan informasi berupa risiko-risiko yang mungkin dihadapi oleh suatu perusahaan (bank syariah) perlu dilakukan secara berimbang, baik informasi yang bersifat positif tetapi perlu juga disampaikan informasi yang sifatnya negatif khususnya berkaitan dengan risiko perusahaan.

Penelitian tentang pentingnya pengungkapan risiko telah dimulai sejak tahun 1998 yang terdapat dalam penelitian Amran, Bin, dan Hassan (2009) yaitu pada tahun 1998 "Institute of Chartered Accountants in English and Wales (ICAEW)" mempublikasikan "Financial Reporting of Risk-Proposals for a Statement of Bussiness Risk" yang berisi tentang saran bagi perusahaan untuk menyajikan pengungkapan tentang risiko bisnis yang dihadapi atau mungkin dihadapinya dalam laporan keuangan. Di Indonesia peraturan mengenai pengungkapan risiko diatur dalam PBI Nomor:5/8/PBI/2003, dan Surat Edaran Ketua Bapepam (P3LKEPPBANK, Tahun 2008)" menerangkan bahwa bank diwajibkan untuk mengungkapkan informasi tentang risiko umum yang 
mereka hadapi. Maka pengungkapan risiko bank syariah di Indonesia merupakan bentuk informasi yang diwajibkan untuk diungkapkan. Menurut Peraturan Otoritas Jasa Keuangan Nomor 65/PJOK.03/2016 pasal 5 mengenai Penerapan Manajemen Risiko untuk Bank Umum Syariah dan Unit Usaha Syariah bahwa bank umum syariah dan unit usaha syariah wajib mengungkapkan 10 jenis risiko yaitu risiko kredit, risiko pasar, risiko likuiditas, risiko operasional, risiko hukum, risiko reputasi, risiko strategik, risiko kepatuhan, risiko imbal hasil dan risiko investasi. Berbeda dengan perbankan konvensional yang hanya mengungkapkan 8 jenis risiko yang wajib diungkapkan dan tidak mengungkapkan risiko imbal hasil dan risiko investasi yang ada pada bank syariah.

Telah banyak penelitian tentang tingkat pengungkapan risiko terhadap perbankan konvensional di Indonesia, tetapi masih sangat sedikit penelitian tentang pengungkapan risiko pada bank syariah di Indonesia. Padahal laju perkembangan bank syariah di Indonesia maju dengan pesat dan banyak masyarakat memercayakan dananya untuk diinvestasikan di bank-bank syariah. Oleh karena itu, pentingnya pengungkapan risiko dapat dijadikan acuan atau informasi bagi para investor/stakeholders mengenai kondisi bank syariah tersebut. Selain itu, penelitian mengenai pengaruh komisaris yang berlatar belakang ekonomi Islam dan dewan komisaris berlatar belakang pensiunan dari otoritas pengawas perbankan syariah pada pengungkapan risiko, masih belum banyak dilakukan. Hal inilah yang menjadi ide penelitian ini dilakukan, dengan variabel yang diteliti antara lain pengaruh ukuran bank syariah (total aset), jumlah cabang bank syariah, likuiditas, kecukupan modal, profitabilitas, jumlah kepemilikan saham publik, komisaris yang berlatar belakang ekonomi Islam dan komisaris berlatar belakang pensiunan otoritas pengawas perbankan syariah pada pengungkapan risiko bank syariah.

Penelitian ini bertujuan untuk menganalisis profitabilitas, kepemilikan saham publik komisaris berlatar belakang ekonomi Islam, komisaris berlatar belakang pensiunan dari otoritas pengawas perbankan syariah terhadap tingkat pengungkapan risiko di bank syariah. Dalam penelitian ini menggunakan desain penelitian deskriptif kuantitatif dari data sekunder berupa annual report bank syariah di Indonesia pada tahun 2012-2018. Objek penelitian ini adalah tingkat pengungkapan risiko bank syariah di Indonesia. Populasi penelitian mencakup seluruh bank umum syariah di Indonesia yang terdaftar di Otoritas Jasa Keuangan dan secara rutin menerbitkan Annual Report pada tahun 2012-2018. Sedangkan sampel dalam penelitian ini yaitu 11 bank umum syariah yang telah menerbitkan annual report lengkap pada tahun 2012 2018.

\section{Teori Stakeholder}

\section{KAJIAN PUSTAKA}

Teori stakeholder dikembangkan oleh Freeman (1984), menyatakan bahwa perusahaan tidak beroperasi hanya untuk mencapai tujuan pemiliknya saja namun juga harus dapat memberi manfaat kepada pemangku kepentingan lainnya (stakeholders). Stakeholders yang dimaksud adalah pemangku kepentingan bank syariah yaitu kreditur,konsumen, pemegang saham, pemerintah, suplier, masyarakat dan pihak lain yang berpartisipasi dalam tercapainya tujuan bank syariah. Maka, kesejahteraan bank syariah bergantung pada dukungan stakeholder.

2. Pengungkapan Risiko pada Bank Syariah

Menurut Peraturan Otoritas Jasa Keuangan Nomor 65/POJK.03/ tahun 2016 menyatakan bahwa risiko merupakan bentuk potensi kerugian akibat terjadinya suatu peristiwa tertentu. Risiko bagi perbankan khususnya bank syariah merupakan suatu kejadian potensial yang dapat diperkirakan maupun yang tidak dapat diperkirakan terhadap pendapatan dan permodalan bank (Fasa, 2016).

2. Komisaris yang Berlatar Belakang Ekonomi Islam Menurut Kusumastuti, Supatmi, dan Sastra (2015) "mengungkapkan anggota dewan komisaris yang berlatar belakang ekonomi dan bisnis memiliki pengetahuan yang lebih baik untuk membuat keputusan bisnis." Hal ini dikarenakan "latar belakang pendidikan dewan komisaris mempengaruhi keputusan dan masukan yang diberikan pada dewan direksi" (Suhardjanto dan Afni, 2016). Disamping latar belakang ekonomi dan bisnis, dalam perbankan syariah, diperlukan juga keputusan-keputusan yang berlandaskan prinsip Islam atau syariah. Untuk itu, diperlukan pula dewan komisaris yang tidak hanya berlatar belakang ekonomi dan bisnis, tetapi juga ekonomi Islam atau ekonomi yang berlandaskan Islam / syariah.

\section{METODE PENELITIAN}

\section{Populasi dan Sampel Penelitian}

Populasi penelitian ini meliputi bank umum syariah di Indonesia yang telah menerbitkan Laporan Tahunan 2012-2018". Sampel penelitian ini meliputi 11 bank umum syariah yang telah mempublikasikan annual report dengan data yang lengkap termasuk 
didalamnya pengungkapan risiko pada tahun 20122018.

Dalam penelitian ini mengunakan teknik nonprobability sampling dimana merupakan tekhnik pengambilan sampel yang tidak memberi peluang / kesempatan yang sama bagi setiap unsur atau anggota populasi untuk dipilih menjadi sampel". Termasuk didalamnya adalah purposive sampling dimana tekhnik penentuan sampelnya dengan pertimbangan atau kriteria tertentu (Wiratna, 2016). Adapun pertimbangan yang digunakan untuk menentukan sampel dalam penelitian ini adalah:

1) Bank syariah yang terdapat di Indonesia untuk periode tahun 2012-2018.

2) Bank syariah yang telah mempublikasikan annual report pada tahun 2012-2018 pada website perusahaan masing-masing.

3) Bank syariah yang memiliki annual report lengkap pada tahun 2012-2018 atau data-data lengkap yang berkaitan atas variabel penelitian.

\section{HASIL DAN PEMBAHASAN}

a) Uji Hipotesis

1. Uji Statistik F

Uji statistik $F$ digunakan untuk mengetahui pengaruh variabel independen terhadap variabel dependen secara bersamasama dengan ketentuan nilai probabilitas signifikansi $<0,05$. Hasil uji statistik $F$ disajikan dalam tabel 7 berikut:

Tabel 7. Uji Statistik F

\begin{tabular}{|c|c|c|c|c|c|c|}
\hline \multicolumn{7}{|c|}{ ANOVA $^{b}$} \\
\hline \multicolumn{2}{|c|}{ Model } & $\begin{array}{c}\text { Sum of } \\
\text { Squares }\end{array}$ & Df & $\begin{array}{l}\text { Mean } \\
\text { Square }\end{array}$ & $\mathrm{F}$ & Sig. \\
\hline \multirow[t]{3}{*}{1} & Regression & 3.879 & 4 & .970 & 6.903 & $.000^{\mathrm{a}}$ \\
\hline & Residual & 10.114 & 72 & .140 & & \\
\hline & Total & 13.993 & 76 & & & \\
\hline
\end{tabular}

a. Predictors: (Constant), LnBidekomsya, LnDekomekis,

LnROA, LnKP

b. Dependent Variable: LnRDI

Sumber: Hasil Analisis SPSS, 2019

Berdasarkan hasil uji statistik F pada tabel 7 di atas, diperoleh nilai $\mathrm{F}$ hitung sebesar 6,903 dengan nilai probabilitas signifikansi sebesar 0,000 ; dimana sig $<0,05$. Hal ini menunjukkan bahwa variabel-variabel independen secara bersama-sama berpengaruh terhadap variabel dependen. Dengan kata lain, profitabilitas (ROA), kepemilikan saham publik (KP), dewan komisaris dengan latar belakang ekonomi Islam
(Dekomekis), dan dewan komisaris dengan latar belakang pensiunan dari otoritas pengawas perbankan syariah (Bidekomsya) memiliki pengaruh secara bersama-sama terhadap vaiabel Tingkat Pengungkapan Risiko/Risk Disclosure Index (RDI) pada bank syariah.

2. Uji Koefisien Determinasi $\left(\mathrm{R}^{2}\right)$

Uji koefisien determinasi $\left(\mathrm{R}^{2}\right)$ dilakukan untuk mengetahui seberapa besar pengaruh variabel independen terhadap variabel dependen secara bersama-sama dengan kriteria $0<\mathrm{R}^{2}<1$; yang disajikan pada tabel 8 berikut:

Tabel Uji 8. Koefisien Determinasi $\left(\mathrm{R}^{2}\right)$

\begin{tabular}{lccccc}
\multicolumn{7}{c}{ Model Summary } \\
\hline Model & $\mathrm{R}$ & R Square & $\begin{array}{c}\text { Adjusted R } \\
\text { Square }\end{array}$ & $\begin{array}{c}\text { Std. Error of } \\
\text { the Estimate }\end{array}$ & $\begin{array}{c}\text { Durbin- } \\
\text { Watson }\end{array}$ \\
\hline 1 & $.526^{\mathrm{a}}$ & .277 & .237 & .3747981 & 1.933 \\
\hline a. Predictors: (Constant), LnBidekomsya, LnDekomekis, LnROA, LnKP \\
b. Dependent Variable: LnRDI
\end{tabular}

Sumber: Hasil Analisis SPSS, 2019

Tabel 8 di atas memperlihatkan hasil statistik nilai koefisien atau Adjusted Square $\left(\mathrm{R}^{2}\right)$ sebesar 0,237; yang berarti kemampuan variabel independen dalam mempengaruhi variabel dependen sebesar 23,7\%. Dapat disimpulkan bahwa, profitabilitas (ROA), kepemilikan saham publik (KP), dewan komisaris dengan latar belakang ekonomi Islam (Dekomekis), dan dewan komisaris dengan latar belakang pensiunan dari otoritas pengawas perbankan syariah (Bidekomsya) memiliki kontribusi pengaruh sebesar 23,7\% terhadap Tingkat Pengungkapan Risiko Bank Syariah, sedangkan sisanya sebesar $76,3 \%$ merupakan kontribusi pengaruh variabel lain diluar penelitian ini.

\section{Uji Statistik t}

Uji statistik t dalam pengujian hipotesis digunakan untuk mengetahui ada tidaknya pengaruh yang signifikan pada setiap variabel independen terhadap variabel dependen. Uji dilakukan dengan melihat nilai $t_{\text {hitung }}>t_{\text {tabel }}$ ( $t_{\text {hitung }}$ $>1,99$ ) dengan signifikansi $<0,05$ atau 5\% maka secara parsial atau individual variabel independen berpengaruh signifikan terhadap variabel dependen yang ditunjukkan pada tabel berikut: 
Tabel 9. Uji Statistik t

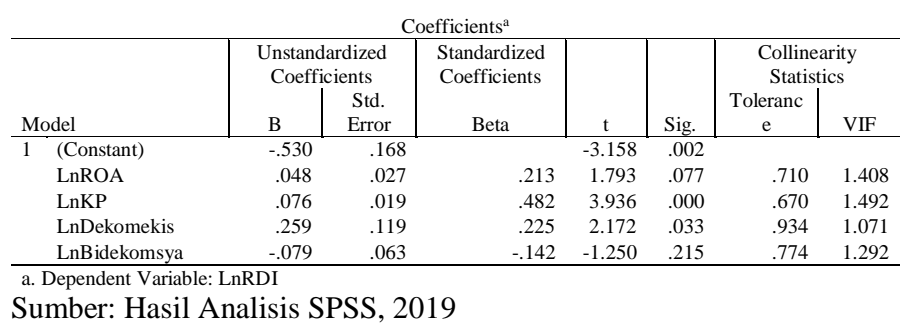

Berdasarkan tabel 9 di atas, dapat diuraikan dengan penjelasan sebagai berikut:

1. Variabel profitabilitas (ROA) memperoleh nilai $t_{\text {hitung }}$ sebesar $-1,793\left(>t_{\text {tabel }}\right)$ dengan nilai signifikansi sebesar 0,077 (sig > 0,05), maka H1 ditolak. Variabel kepemilikan saham publik (KP) memperoleh nilai thitung sebesar 3,936 ( $\left.>t_{\text {tabel }}\right)$ dengan nilai signifikansi sebesar 0,000 ( sig <0,05), maka $\mathrm{H} 2$ diterima.

2. Variabel dewan komisaris dengan latar belakang ekonomi Islam (Dekomekis) memperoleh nilai $t_{\text {hitung }}$ sebesar 2,172 $\left(>t_{\text {tabel }}\right)$ dengan nilai signifikansi sebesar 0,033 (sig < 0,05), maka $\mathrm{H} 3$ diterima.

3. Variabel dewan komisaris dengan latar belakang pensiunan dari otoritas pengawas perbankan syariah (Bidekomsya) memperoleh nilai thitung sebesar $-1,250\left(<\mathrm{t}_{\text {tabel }}\right)$ dengan nilai signifikansi sebesar 0,215 ( $\mathrm{sig}>0,05)$, maka H4 ditolak.

Pembahasan

1. Pengaruh Dewan Komisaris dengan Latar Belakang Ekonomi Islam terhadap Tingkat Pengungkapan Risiko

Berdasar hasil pengolahan data menunjukkan Variabel dewan komisaris dengan latar belakang ekonomi Islam (Dekomekis) memperoleh nilai thitung sebesar 2,172 ( $>t_{\text {tabel }}$ ) dengan nilai signifikansi sebesar 0,033 (sig < 0,05), maka H3 diterima. Dengan kata lain, variabel dewan komisaris dengan latar belakang ekonomi Islam secara parsial memiliki pengaruh yang signifikan terhadap tingkat pengungkapan risiko bank syariah. Berdasar statistik deskriptif dewan komisaris yang berlatar belakang ekonomi Islam memperoleh nilai rata-rata sebesar 0,40 dengan rentangan nilai minimum hingga maksimum sebesar 0,17 hingga 1,00 dan standar deviasi sebesar 0,16. Berdasarkan analisis laporan tahunan menunjukkan bahwa dewan komisaris yang berlatar belakang ekonomi Islam masih relatif sedikit dengan nilai rata-rata $40 \%$ dari jumlah keseluruhan dewan komisaris bank syariah. Peraturan OJK mengharuskan bank umum syariah untuk memiliki komisaris dengan latar belakang ekonomi islam atau syariah setidaknya 2 sampai 5 orang.dari data penelitian dan hasil olah data menunjukkan bahwa rata-rata bank syariah yang memiliki komisaris berlatar belakang ekonomi islam yang tinggi, pengungkapan risiko nya cenderung tinggi. Hal ini dikarnakan komisaris dengan latar belakang ekonomi dan bisnis memiliki kemampuan yang lebih baik dalam membuat keputusan bisnis. Terlebih lagi bank syariah yang berlandaskan Islam, tidak hanya memerlukan dewan komisaris yang berlatar belakang ekonomi dan bisnis saja, tetapi juga ekonomi yang berlandaskan syariat Islam pula. Sehingga dewan komisaris dengan latar belakang ekonomi Islam sangat dibutuhkan sebagai pengawas guna mengetahui dan menganalisis risiko yang dihadapi serta dalam pengambilan keputusan berdasarkan syariat Islam. Penelitian yang dilakukan oleh Suhardjanto (2016) juga berpendapat bahwa komisaris dengan latar belakang pendidikan ekonomi islam dapat mendorong perusahaan dalam melakukan pengungkapan risiko secara lebih mendalam.

2. Pengaruh Dewan Komisaris dengan Latar Belakang Pensiunan dari Otoritas Pengawas Perbankan Syariah terhadap Tingkat Pengungkapan Risiko

Berdasarkan analisis regresi, menunjukkan Variabel dewan komisaris dengan latar belakang pensiunan dari otoritas pengawas perbankan syariah (Bidekomsya) memperoleh nilai $t_{\text {hitung }}$ sebesar $-1,250\left(<\mathrm{t}_{\text {tabel }}\right)$ dengan nilai signifikansi sebesar 0,215 ( $\mathrm{sig}>0,05$ ), maka H4 ditolak. Dapat dikatakan bahwa variabel dewan komisaris dengan latar belakang pensiunan dari otoritas pengawas perbankan syariah tidak memiliki pengaruh yang signifikan secara parsial terhadap tingkat pengungkapan risiko bank syariah. Hal ini mengindikasikan komposisi dewan komisaris yang berlatar belakang 
pensiunan dari otoritas pengawas perbankan syariah hanya sekitar $18 \%$ dari jumlah keseluruhan komposisi dewan komisaris bank syariah atau dikaktegorikan masih sangat rendah. Data penelitian dan hasil olah data menunjukkan bahwa rata-rata bank syariah yang memiliki komisaris berlatar belakang pensiunan dari Otoritas Pengawas Perbankan Syariah yang tinggi, pengungkapan risiko yang dilakukan cenderung rendah. Hal ini karena dewan komisaris sebagai pengawas pelaksanaan kegiatan operasional bank syariah di Indonesia masih sangat rendah, sehingga karena dewan komisaris berlatarbelakang pensiunan otoritas pengawas perbankan syariah yang rendah menyebabkan informasi terkait risiko tidak diungkapkan secara menyeluruh.

Penelitian ini berbeda dengan penelitian Adiyanto (2015) yang menjelaskan bahwa komisaris yang berlatar belakang pensiunan dari otoritas pengawas perbankan syariah memiliki pengaruh yang signifikan terhadap tingkat pengungkapan risiko; dimana personalia yang pernah bekerja di lembaga pengawasan bank, memiliki pengetahuan, kemampuan, serta pengalaman dalam pengawasan perbankan, sehingga mampu menuntut pihak manajemen dalam melakukan pengungkapan secara lebih mendalam. Abdul dan Mohamed (2015) menjelaskan pula bahwa komisaris yang telah memiliki pengalaman dalam lembaga pengawasan perbankan dapat meningkatkan pengungkapan risiko. Hasil penelitian ini berbeda dengan penelitian sebelumya, dikarenakan berdasarkan data, rata-rata dewan komisaris yang berlatar belakang pensiunan otoritas pengawas perbankan syariah di Indonesia masih sangat rendah.

\section{KESIMPULAN DAN SARAN}

Penelitian ini bertujuan untuk mengetahui hubungan atau pengaruh profitabilitas, kepemilikan saham publik, dewan komisaris dengan latar belakang ekonomi Islam dan dewan komisaris dengan latar belakang pensiunan dari otoritas pengawas perbankan syariah terhadap tingkat pegungkapan risiko (risk disclosure) bank syariah di Indonesia. Data dalam penelitian ini merupakan data sekunder yang diperoleh dari laporan tahunan bank syariah dari tahun 20122018. Berdasarkan analisis regresi, menunjukkan Variabel dewan komisaris dengan latar belakang pensiunan dari otoritas pengawas perbankan syariah (Bidekomsya) memperoleh nilai thitung sebesar $-1,250(<$ ttabel $)$ Dapat dikatakan bahwa variabel dewan komisaris dengan latar belakang pensiunan dari otoritas pengawas perbankan syariah tidak memiliki pengaruh yang signifikan secara parsial terhadap tingkat pengungkapan risiko bank syariah. Hal ini karena dewan komisaris sebagai pengawas pelaksanaan kegiatan operasional bank syariah di Indonesia masih sangat rendah, sehingga karena dewan komisaris berlatarbelakang pensiunan otoritas pengawas perbankan syariah yang rendah menyebabkan informasi terkait risiko tidak diungkapkan secara menyeluruh.

Berdasarkan kesimpulan hasil penelitian dan beberapa keterbatasan penelitian di atas, maka saran yang dapat diberikan sebagai berikut:

1. Pihak manajemen dapat menjadikan motivasi guna meningkatkan kinerja manajemen dalam pengungkapan risiko yang lebih transparan dan lebih mendetail serta menerapkan good corporate governance yang lebih baik lagi.

2. Bagi pemerintah atau instansi terkait seperti Bank Indonesia / Otoritas Jasa Keuangan agar mengevaluasi pengungkapan risiko pada bank syariah sehingga pengungkapan risiko akan lebih optimal dilaksanakan oleh setiap bank syariah.

3. Bagi penelitian selanjutnya, dapat memperluas populasi penelitian bank syariah selain di Indonesia atau memperluas periode tahun penelitian yang digunakan atau variabel lain yang diduga memiliki pengaruh terhadap tingkat pengungkapan risiko bank syariah.

\section{REFERENSI}

[1] Abdul Rahman, R., Ibrahim, Z., Tohirin, A., Muhammad, A. D., \& Suryaputri, R.V. (2015). Risk Management practices in islamic banking institutions: Malaysia and Indonesia in comparative 
perspective.Accounting Research Institute, University Technology MARA, Malaysia.

[2] Abdul, Rahman R and Mohamed, Ali F H. 2015. "Board, Audit Committee, Culture and Earnings Management: Malaysian Evidence". Managerial Auditing Journal, Vol. 21, No. 7, pp. 783- 804.

[3] Abraham, S dan P. Cox. 2007. "Analyzing The determinants of Narrative Risk Information in UK FTSE 100 Annual Reports." British Accounting Review. Vol. 39. No.3. PP. 227-248.

[4] Adiyanto, Harri Baskoro. 2015. Faktorfaktor yang Mempengaruhi Tingkat Pengungkapan Risiko Perusahaan (Corporate Risk Disclosure) pada Industri Perbankan Indonesia. Jurnal Akuntansi , 16 (3): 95-120

[5] Agustina, Cintia Heko. 2014. "Pengaruh Kompetisi, Corporate Governance, Struktur Kepemilikan Terhadap Pengungkapan Risiko". Jurnal Akuntansi dan Auditing Vol. 15 No. 2 pp 22-96.

[6] Agustini dan Ulum, 2014. Memahami Manajemen Risiko Perbankan Syariah.http://deoue.wordpress.com/2010/0 1/25/manajemen-risiko-perbankansyariah/. Diakses pada 20 April 2019.

[7] Aljifri, Khaled dan Khaled Hussainey. 2012. "The Determinant of Forward Looking Information in Annual Reports of UAE." International bussiness Review. Vol. 16. No.1. PP.

[8] Amran, A., A.M.R. Bin, dan B.C.H.M. Hassan. 2009. An Exploratory Study on Risk Disclosure in Malaysian Annual Reports. Managerial Auditing Journal Vol. 24 No. 1: 39-57.

[9] Anisa, Wendy Gessy dan Prastiwi, Andri. 2012. "Analisis Faktor Yang Mempengaruhi Pengungkapan Manajemen Risiko. Jurnal Akuntansi Vol. 20 No. 2 pp 17-56.

[10] Aprilia, Tri Farziana, 2014, Faktor yang Mempengaruhi Pengungkapan Manajemen Risiko (Studi Empiris Pada Perusahaan Pertambangan Konsumsi yang Terdaftar di
BEI ). Jurnal Manajemen Indonesia Vol. 20 No. 3 pp 33-46.

[11] Aziz, A. 2016. Analisis Pengaruh Struktur Kepemilikan dan Karakteristik perusahaan terhadap tingkat Pengungkapan Risiko (Studi pada Perusahaan Manufaktur 2011 2014). Jurnal Akuntansi Vol. 25 No. 3 pp 35-78.

[12] Bank for International Settlements. 2012. 2012 Core Principles for Effective Banking Supervision. Basel, Switzerland, Bank for International Settlements

[13] Chapra, M.U. 2015. The Future of Economic: An Islamic Perspective. diterjemahkan oleh Amdiar Amir dkk, "Landscape Baru Perekonomian Masa Depan”. Jakarta: SEBI, hal 131.

[14] Chariri, A., \& Ghozali, I. (2007). Teori Akuntansi. Semarang: Badan Penerbit Universitas Diponegoro.

[15] Clarkson, P.M., Kao, J.L., \& Richardson, G.D. (1994). Evidence that management discussion and analysis (MD\&A) is a part of a firm's overall disclosure package. Contem- porary Accounting Research, 16 (1), 111-134.

[16] Daniri, Mas Achmad. 2014. Lead By GCG. Jakarta: Gagas Bisnis Indonesia.

[17] Davis, E. Philip dan Ugochi Obasi. 2009. The Effectiveness of Banking Supervision. London: Brunel University Department of Economics and Finance.

[18] Dendawijaya, Lukman, 2005, Manajemen Perbankan, Penerbit Ghalia Indonesia, Jakarta.

[19] Donaldson, Thomas dan Lee E. Preston. 1995. The Stakeholder Theory of the Corporation: Concepts, Evidence, and Implications. The Academy of Management Review, Vol. 20, No. 1 (Jan 1995), hlm. 6591 http://www.jstor.org/stable/258887.

[20] Elzahar, Hany dan Khaled Hussainey. 2012. Determinants of Narrative Risk Disclosures in UK Interim Reports. The Journal of Risk Finance 02/2012; 13(2):133-147. 
[21] Fauroni, L. 2015. Arah dan Strategi Ekonomi Islam. Yogyakarta: Magistra Insania Press.

[22] Faisol, Ahmad, 2007, Analisis Kinerja Keuangan Bank Pada PT. Bank Muamalat Indonesia Tbk, hal 129-170.

[23] Ferry N. Idroes, Manajemen Risiko Perbankan, Cetakan ke-2, Jakarta: PT. RajaGrafindoPersada, 2011, h. 4.

[24] Fikri, A dalam Mustafa Kamal. 1997. Wawasan Islam dan Ekonomi Sebuah
Bunga Rampai. Jakarta: Lembaga Penerbit Fakultas Ekonomi Universitas Indonesia, hal 112

[25] Freeman, R. Edward and John McVea. 2001. A Stakeholder Approach to Strategic Management. Darden Business School Working Paper No. 01-02. Available at SSRN: http://ssrn.com/abstract $=263511$ or http://dx.doi.org/ 10.2139/ ssrn.26 